\title{
Comparative overview of transfer pricing tax regulation in the world
}

\section{Компаративни преглед пореске регулације трансферних цијена у свијету}

\author{
Љиљана Танасић* \\ Универзитет у Источном Сарајеву, Економски факултет Брчко, Брчко
}

\begin{abstract}
Along with the process of globalization and the increase of cross-border business, transfer pricing, as a medium of transactions between related legal entities, receives the epithet of one of the biggest challenges of national tax systems. However, the effects of individual actions of each country in the domain of addressing the potential risks of transfer pricing are largely limited, thus the emphasis is put on international cooperation and activities in terms of systemic resolution of the problem concerned. Based on the above, the paper shows comparative overview of the tax regulations of individual countries in the world (classified by continents) in the domain of using transfer pricing, stating whether international regulation applies on that basis or not and on which segments.
\end{abstract}

Keywords: transfer pricing, tax base deduction, international regulation, international organizations, regional organizations

Сажетак: Са процесом глобализације и све израженијим прекограничним пословањем, трансферне цијене, као носиоци трансакција између повезаних правних лица, добијају епитет једног од највећих изазова националним пореским системима. Међутим, ефекти самосталног, односно индивидуалног дјеловања сваке земље у домену рјешавања потенцијалног ризика примјене трансферних цијена су углавном ограничени, те се из тог разлога акценат ставља на међународну сарадњу и активности у погледу системског рјешавања односног проблема. Кључну улогу у томе имају међународна тијела и регионалне организације. Водећи се наведеним, у раду је дат компаративни преглед пореских прописа појединих земаља у свијету (разврстаних по континентима) у домену примјене трансферних цијена, уз навођење да ли и у којим сегментима се по том основу примјењује међународна регулатива.

Кључне речи: трансферне цијене, умањење пореске обавезе, међународна регулатива, међународна тијела, регионалне организације

\section{Introduction}

Modern business conditions have brought forth a number of changes to the world's business scene. As the architect and the greatest support to trade liberalization, i.e. creation of free trade, globalization played the most important role in shaping marketeconomic relations in the broader, worldwide sense. The erosion of national sovereignty and national borders caused, inter alia, the development of global financial

*هljiljana.tanasic.efb@gmail.com 
systems, an increase in international capital flows, foreign direct investment and participation of multinational business entities in the world economy. In other words, the higher rate of growth in international trade, in comparison to the growth rate of the world economy, has tightened the conditions of survival in the market and has led to increasingly expressive tendencies of various combinations of the so-called business within a group of related legal entities. Accession to the group and business within the group provides a greater degree of market stability and security in terms of procurement of goods and services, as well as in terms of their placement.

However, transactional relationships between related legal entities and transfer pricing on this basis do not constitute an intriguing topic only for the accounting sector, but for the tax authorities when drafting national taxation rules for participants of different business combinations as well. One of the most significant manifestations of this problem at the international level is the relaying of a taxable profit to the tax jurisdiction with a more favourable tax regime, through transactional relations between related legal entities, relying on the transfer pricing policy. Namely, since the mechanisms of allocation of costs and overhead are subjective, 'such discretion can enable them to minimise taxes and thereby swell profits by ensuring that, wherever possible, most profits are located in low-tax or low risk jurisdictions' (Sikka \& Willmott, 2010, p. 342). Such activities of allocating the capital of one taxpayer to multiple tax jurisdictions leave direct implications for the tax systems and tax revenues of individual countries. The amount of lost tax revenue from fraudulent use of transfers pricing, especially in countries where there are no complete legal and control mechanisms to regulate them, are difficult to determine, but according to some estimates they exceed as much as US $\$ 100$ billion in tax revenue annually (see Jansky $\&$ Prats, 2015, p. 275, see Berkhout, 2016, p. 3).

The listed problem prompted the reaction of various international and regional organizations and institutions in finding appropriate, acceptable solutions that would facilitate the avoidance of international disputes and international double taxation, reduction of risk for the arbitration corrections of transfer prices and increasing legal security, through the simplification and harmonization of the procedure for proving transfer prices, that is, through the standardization of the procedure and documentation itself.

In order to show whether and to what extent the application of transfer pricing is regulated by the relevant tax regulations in countries around the world, and whether these regulations are based on international guidelines, the paper show comparative review of transfer pricing tax regulation of selected countries classified by continents.

\section{Activities of international institutions and organizations in the field of regulating the tax treatment of transfer pricing}

International organizations such as the Organisation for Economic Co-operation and Development (OECD), the European Union (EU), the United Nations (UN), the International Monetary Fund (IMF), the World Bank (WB) have devoted considerable 
attention to the resolving the problem of the application of transfer pricing policy at the international level. Certain regional organizations such as the African Tax Administration Forum, the EU Joint Transfer Pricing Forum and the Inter-American Centre of Tax Administrations have also been included in these activities.

The OECD, which is increasingly gaining the status of an informal global centre dealing with tax policy issues, has issued several frameworks, recommendations, brochures and guidelines for formulation of transfer pricing. Their task has been constricting freedom in defining transfer pricing in the field of implementation of controlled transactions. One of the most important documents, when it comes to its prevalence, is the OECD Transfer Pricing Guidelines for Multinational Enterprises and Tax Administrations. This document is considered as the most significant and most accepted model for determining and controlling transfer prices.

The aforementioned document (see OECD, 2017) defines the arm's length principle as a basis for determining transfer pricing, which implies the use of the price that can be achieved between completely independent economic entities for certain goods or services, in the conditions of free competition. The implementation of the arm's length principle ensures 'uniform tax treatment for all taxpayers, whether or not they are considered to be related' (Negovanović, Čubrić \& Lazović, 2015, p. 24). As approved methods, traditional transaction methods (comparable uncontrolled price method, resale price method, cost plus method) and transactional profit methods (transaction net margin method, transaction profit split method) are listed in the OECD Guidelines. Also, the OECD Guidelines support appropriate transfer pricing agreements, which are made by related legal entities with national tax administrations. These agreements are called Advance Pricing Arrangements (APAs) and represent a special form of contract between the taxpayer (as a member of an economic entity) and the competent tax authority, in terms of defining the criteria for determining transfer prices for certain transactions for the defined future time period. In other words, such contracts cover more of the coming years and thus reduce the need for an audit during this period, reduce uncertainty, risk for investors as well as compliance costs (see Becker et al., 2017, p. 256). The purpose of applying this contract is to strengthen trust between tax authorities and taxpayers.

The OECD Guidelines also provide instructions for the implementation of a reliable comparability analysis, as well as rules and recommendations for the compilation of transfer pricing documentation, and recommendations and instructions related to other segments regarding the application of transfer pricing (transfer of intangible assets, special fees for services within the group, disputes resolution on transfer pricing and business restructuring issues).

As the most important benefits of a successful implementation of the OECD Guidelines are stated (King, 2009, p. 183):

- Enable tax authorities in different jurisdictions to allocate income across the countries in which multinational firms operate both equitably and consistently, and thereby prevent double-taxation; 
- Provide some certainty to firms regarding their tax liability; and,

- Minimize compliance, audit and dispute resolution costs.

In order to prevent erosion of the national tax base and shifting profits between individual tax jurisdictions, the OECD also initiated The Base Erosion and Profit Shifing (BEPS) project, whose Action Plan consists of 15 actions (see OECD, 2013), tasked to equip tax authorities with national and international instruments for resolving the problem of tax avoidance, ensuring that profits are taxed in the jurisdiction where profit-generating economic activities are perform and where is value created. Four (8, 9, 10 and 13) of these 15 actions are related to the regulation of transfer pricing.

Regarding the application of the transfer pricing regulation in the area of composing the transfer pricing documentation, EU has issued documents and codes that generally rely on the OECD Guidelines, with possible simplification and standardization of regulations for multinational business entities operating in the EU territory and, therefore, are legally obliged to compile and present reports to tax administrations of EU member states (see Europian Union, 2006).

Within the UN Department of Economic and Social Affairs (DESA), the Committee of Experts on International Cooperation in Tax Matters published the Practical Manual on Transfer Pricing for Developing Countries which is, to a large extent, based on the principles set out in the OECD Guidelines (see United Nation, 2017).

The IMF and the WB have also been involved in the activities related to the regulation of transactional relations at the international level, inter alia in the provision of various forms of support to developing countries in building the necessary capacities for adequately mastering tax issues.

From the point of view of regional organizations participation, the platforms for mutual cooperation of tax administrations encourage the exchange of experiences and information, share views on tax issues and best practices, provide services in the form of technical assistance, foster development of studies, conducting trainings, seminars etc., all for the purpose of institutional strengthening of member states tax administrations. In this way, these organizations significantly contribute to the alignment of tax regulations and practices in the area of transfer pricing, all in line with the needs and strategies of their members.

\section{Presentation of transfer pricing tax treatment in the world}

By examining the tax treatment of transfer pricing for selected countries around the world, this part of paper shows how far some countries have come in terms of regulating and mutually aligning related issues. The existing legislation is the basis for the implementation of tax control in order to narrow the space for abuse of transfer pricing, as a means of reducing the tax liability of the entire group of related legal entities. Non-harmonized regulations, significant variations and incomplete or no legal regulation of particular areas of application make the ground for ever more intense 
'walking' of business profits between different tax jurisdictions. Therefore, harmonization and standardization of national tax regulations in this field, with agreed means of verifying the correct use of them (e.g. the use of appropriate databases for finding the same or similar transactions between unrelated legal entities), in countries taxing profits, would eliminate, or at least reduce, the possibilities of their tax abuse.

Presentation of the tax treatment of transfer pricing in selected countries is based on the consideration of the annual reports of various international consulting companies for year 2018 and of the review of the annual corporate income tax rates for 2018 certain international consulting companies and organizations.

In the selection of the countries considered, the principle of a diversified approach to tax regulation of transfer prices was used to emphasize the diversification of legal regulation, not only between continents but also within them. This review covers countries with relatively highest and lowest corporate income tax rates across each continent, with the exception of countries classified as 'tax havens' (due to the absence of any legal formulation of transfer pricing) and countries that have prescribed corporate tax rates only for a particular industry or sector, while other branches or sectors are tax-free on that basis.

\subsection{Tax treatment of transfer prices in America}

The national tax administrations in America, in the area of regulation and harmonization of transfer pricing tax regulations, rely on the work and support of the Inter-American Centre of Tax Administrations, which was established in 1967, and today consists of 40 member states. However, the way of regulating the issue of transfer pricing in different parts of America is not consistent, and it can be said that there are variations in the level of resolution and legal comprehensiveness between its southern and western part.

Table 1. Summary of transfer pricing tax treatment in selected North American countries

\begin{tabular}{|l|c|c|c|c|c|}
\hline Country & Guatemala & Canada & Costa Rica & Puerto Rico & USA \\
\hline $\begin{array}{l}\text { Corporate income tax } \\
\text { rate }\end{array}$ & $25 \%$ & $26.8 \%$ & $30 \%$ & $39 \%$ & $25.84 \%$ \\
\hline Regulation type & $\begin{array}{c}\text { National } \\
\text { regulations }\end{array}$ & $\begin{array}{c}\text { National } \\
\text { regulations }\end{array}$ & $\begin{array}{c}\text { National } \\
\text { regulations }\end{array}$ & $\begin{array}{c}\text { National } \\
\text { regulations }\end{array}$ & $\begin{array}{c}\text { National regulations } \\
\text { (in line with the } \\
\text { OECD) }\end{array}$ \\
\hline $\begin{array}{l}\text { Transfer pricing } \\
\text { regulations }\end{array}$ & Yes & $\begin{array}{c}\text { Yuidelines are } \\
\text { used, although } \\
\text { Canada is not a } \\
\text { member) }\end{array}$ & $\begin{array}{c}\text { Yes (OECD } \\
\text { Guidelines are } \\
\text { used, although } \\
\text { Costa Rica is not a } \\
\text { member) }\end{array}$ & Yes & Yes (OECD \\
Guidelines are used) \\
Transfer pricing methods & $\begin{array}{c}\text { Yes (all } \\
\text { methods listed } \\
\text { Guidelines, } \\
\text { while } \\
\text { preference is } \\
\text { given to } \\
\text { traditional } \\
\text { transactional }\end{array}$ & $\begin{array}{c}\text { Yes (all } \\
\text { in the OECD } \\
\text { Guidelines) }\end{array}$ & $\begin{array}{c}\text { Yes (all methods } \\
\text { listed in the } \\
\text { OECD } \\
\text { Guidelines) }\end{array}$ & $\begin{array}{c}\text { Yes (respecting } \\
\text { the arm's length } \\
\text { principle) }\end{array}$ & $\begin{array}{c}\text { Guidelines, but the } \\
\text { allowed methods } \\
\text { differing depending } \\
\text { on the type of } \\
\text { transaction) }\end{array}$ \\
\hline
\end{tabular}




\begin{tabular}{|c|c|c|c|c|c|}
\hline & methods) & & & & \\
\hline $\begin{array}{l}\text { Transfer pricing } \\
\text { documentation }\end{array}$ & Yes & Yes & $\begin{array}{l}\text { Yes (but only as a } \\
\text { statement that the } \\
\text { controlled } \\
\text { transactions are in } \\
\text { accordance with } \\
\text { the arm's length } \\
\text { principle) }\end{array}$ & Yes & Yes \\
\hline $\begin{array}{l}\text { Requirements to prepare } \\
\text { documentation annually }\end{array}$ & $\begin{array}{l}\text { With the annual } \\
\text { tax return }\end{array}$ & $\begin{array}{l}6 \text { months after } \\
\text { the end of the } \\
\text { fiscal year }\end{array}$ & Not defined & Not defined & Not defined \\
\hline $\begin{array}{l}\text { Submission deadline upon } \\
\text { request by tax authorities }\end{array}$ & 20 days & 6 months & Not defined & 30 days & 30 days \\
\hline $\begin{array}{l}\text { Tax penalties for } \\
\text { underestimation of tax } \\
\text { base based on the use of } \\
\text { transfer pricing }\end{array}$ & Not defined & $\begin{array}{l}10 \text { of the } \\
\text { determined tax } \\
\text { surcharge }\end{array}$ & Not defined & $\begin{array}{l}10 \% \text { of the } \\
\text { determined tax } \\
\text { surcharge }\end{array}$ & $\begin{array}{l}20-40 \% \text { of the } \\
\text { determined tax } \\
\text { surcharge }\end{array}$ \\
\hline$A P A$ & Yes & Yes & Yes & No & Yes \\
\hline $\begin{array}{l}\text { Time limit for concluding } \\
\text { APA }\end{array}$ & 4 years & $\begin{array}{c}\text { Minimum } 3 \\
\text { years }\end{array}$ & 3 years & - & 5 years \\
\hline$B E P S$ & $\begin{array}{c}\text { Not } \\
\text { incorporated } \\
\text { into legal } \\
\text { regulations } \\
\end{array}$ & $\begin{array}{c}\text { Not } \\
\text { incorporated } \\
\text { into legal } \\
\text { regulations } \\
\end{array}$ & $\begin{array}{l}\text { Not incorporated } \\
\text { into legal } \\
\text { regulations }\end{array}$ & $\begin{array}{l}\text { Not incorporated } \\
\text { into legal } \\
\text { regulations }\end{array}$ & $\begin{array}{l}\text { Partly incorporated } \\
\text { into legal regulations }\end{array}$ \\
\hline $\begin{array}{l}\text { Databases for comparing } \\
\text { controlled and } \\
\text { uncontrolled transactions }\end{array}$ & Do not apply & S\&P Capital IQ & Do not apply & Do not apply & $\begin{array}{c}\text { S\&P Capital IQ, } \\
\text { Compustat (and } \\
\text { others) }\end{array}$ \\
\hline
\end{tabular}

Source: Table created by the author, based on data EY (2017/18), PKF (2017/18), Deloitte (2018), KPMG (2018), OECD (2018), PwC (2018), Tax Foundation (2018)

The average corporate income tax rate in North America is 26.75\% (according to KPMG). Based on the data presented in the table, it is noted that in the countries of North America tax issues are regulated exclusively by national regulations. In some countries (such as the US) national regulations are in line with OECD regulations. There are transfer pricing regulations, relying mainly on the OECD Guidelines (although some countries do not have a member status), but in case of non-compliance, individual countries (e.g. Mexico) give preference to national regulations. With different variations of priority, all the methods outlined in the Guidelines are used (in Puerto Rico, which according to the Tax Foundation has the highest corporate income tax rate in the North American Territory, no transfer pricing methods are legally defined, but only indicated that they should be in line with the arm's length principle). The transfer pricing documentation is mandatory (although some countries, such as Costa Rica, require only a statement of compliance with the arm's length principle in carrying out controlled transactions). However, in some countries, there is no obligation to periodically submit transfer pricing documentation (among the countries under consideration are the USA and Costa Rica), and in some countries the deadline for submitting the relevant documentation at the request of the competent tax authorities is not even defined. Regarding the prescribed penalties for potential misuse of transfer pricing in the settlement of tax liabilities, the situation is diverse and, in certain countries (e.g. Guatemala, Costa Rica) there is complete absence of misuse penalties. Implementation of APA is also represented in a number of countries (among the countries under consideration Puerto Rico is the exception). The BEPS project is not incorporated into the law of North American countries or it is incorporated in some 
limited (partial) form. In doing so, some countries do not apply databases for comparisons controlled with uncontrolled transactions, while countries, such as Canada and the USA, support the use of certain databases.

Table 2. Summary of transfer pricing tax treatment in selected South American countries

\begin{tabular}{|c|c|c|c|c|c|}
\hline Country & Argentina & Brazil & Paraguay & Peru & Chile \\
\hline Corporate income tax rate & $30 \%$ & $34 \%$ & $10 \%$ & $29.5 \%$ & $26 \%$ \\
\hline Regulation type & $\begin{array}{l}\text { National } \\
\text { regulations }\end{array}$ & $\begin{array}{l}\text { National } \\
\text { regulations }\end{array}$ & $\begin{array}{l}\text { National } \\
\text { regulations }\end{array}$ & $\begin{array}{l}\text { National } \\
\text { regulations (in } \\
\text { line with the } \\
\text { OECD, although } \\
\text { Peru is not a } \\
\text { member) }\end{array}$ & National regulations \\
\hline $\begin{array}{l}\text { Transfer pricing } \\
\text { regulations }\end{array}$ & $\begin{array}{c}\text { Yes (OECD } \\
\text { Guidelines are } \\
\text { used, although } \\
\text { Argentina is not a } \\
\text { member, but in } \\
\text { case of non- } \\
\text { compliance, } \\
\text { priority is given to } \\
\text { national } \\
\text { regulations) }\end{array}$ & Yes & No & $\begin{array}{l}\text { Yes (OECD } \\
\text { Guidelines are } \\
\text { used, but in case } \\
\text { of non- } \\
\text { compliance, } \\
\text { priority is given } \\
\text { to national } \\
\text { regulations) }\end{array}$ & Yes \\
\hline Transfer pricing methods & $\begin{array}{l}\text { Yes (all methods } \\
\text { listed in the } \\
\text { OECD } \\
\text { Guidelines) }\end{array}$ & $\begin{array}{l}\text { Yes (with the } \\
\text { difference } \\
\text { between import } \\
\text { and export } \\
\text { transactions) }\end{array}$ & Not defined & $\begin{array}{l}\text { Yes (all methods } \\
\text { listed in the } \\
\text { OECD } \\
\text { Guidelines) }\end{array}$ & Yes \\
\hline $\begin{array}{l}\text { Transfer pricing } \\
\text { documentation }\end{array}$ & Yes & Yes & No & Yes & $\begin{array}{l}\text { Yes (but only as a } \\
\text { statement that the } \\
\text { controlled } \\
\text { transactions are in } \\
\text { accordance with the } \\
\text { arm's length } \\
\text { principle) }\end{array}$ \\
\hline $\begin{array}{l}\text { Requirements to prepare } \\
\text { documentation annually }\end{array}$ & $\begin{array}{l}8 \text { months after the } \\
\text { end of the } \\
\text { reporting year }\end{array}$ & $\begin{array}{l}\text { January } 31 \text { (for } \\
\text { the previous year) }\end{array}$ & - & $\begin{array}{l}\text { July (for the } \\
\text { previous year) }\end{array}$ & $\begin{array}{l}\text { July (for the } \\
\text { previous year) }\end{array}$ \\
\hline $\begin{array}{l}\text { Submission deadline upon } \\
\text { request by tax authorities }\end{array}$ & 15 days & 20 days & - & Not defined & Immediately \\
\hline $\begin{array}{l}\text { Tax penalties for } \\
\text { underestimation of tax } \\
\text { base based on the use of } \\
\text { transfer pricing }\end{array}$ & $\begin{array}{c}\approx 2.230,00 € \\
\text { (converted } \\
\text { amount) }\end{array}$ & Not regulated & - & $\begin{array}{l}0.6 \% \text { of the net } \\
\text { profit that } \\
\text { precedes the } \\
\text { analysed profit }\end{array}$ & $\begin{array}{l}5 \% \text { of the } \\
\text { determined tax } \\
\text { surcharge }\end{array}$ \\
\hline$A P A$ & No & No & No & Yes & Yes \\
\hline $\begin{array}{l}\text { Time limit for concluding } \\
\text { APA }\end{array}$ & - & - & - & 3 years & $3-5$ years \\
\hline$B E P S$ & $\begin{array}{l}\text { Partly } \\
\text { incorporated into } \\
\text { legal regulations }\end{array}$ & $\begin{array}{l}\text { Not incorporated } \\
\text { into legal } \\
\text { regulations }\end{array}$ & $\begin{array}{l}\text { Not } \\
\text { incorporated } \\
\text { into legal } \\
\text { regulations } \\
\end{array}$ & $\begin{array}{l}\text { Incorporated into } \\
\text { legal regulations }\end{array}$ & $\begin{array}{l}\text { Not incorporated } \\
\text { into legal } \\
\text { regulations }\end{array}$ \\
\hline $\begin{array}{l}\text { Databases for comparing } \\
\text { controlled and } \\
\text { uncontrolled transactions }\end{array}$ & Do not apply & Do not apply & Do not apply & Any database & Do not apply \\
\hline
\end{tabular}

Source: Table created by the author, based on data EY (2017/18), PKF (2017/18), Deloitte (2018), KPMG (2018), OECD (2018), PwC (2018), Tax Foundation (2018)

The average corporate income tax rate in South America is 28.05\% (according to KPMG). In the analyzed countries of South America, tax issues are regulated by national regulations, but in some countries they are aligned with OECD regulations. There are transfer pricing regulations and prescribed transfer pricing methods in most 
South American countries (among the countries under consideration the exception is Paraguay, which, according to the Tax Foundation, has the lowest corporate income tax rate in this continent), which, in some countries, rely on the OECD Guidelines (although they do not have a member status). There are also countries (like Brazil) which have not adopted the arm's length principle. Transfer pricing documentation is generally mandatory (Paraguay is the exception among the considered ones), but regulations relating to tax penalties based on the manipulative application of transfer pricing vary considerably, and for a number of countries (such as Brazil, which is classified among the countries with the highest corporate income tax rate in this continent, according to Tax Foundation) are non-existent. APAs are permitted in individual countries in the territory of South America (e.g. Peru and Chile), but are tailored to each country's national estimates. Legislation is different in South American countries regarding to the incorporation of the BEPS Action Plan, while databases for comparisons of controlled and uncontrolled transactions generally do not apply (the exception for the considered countries is Peru where the competent tax authorities rely on both local and foreign databases).

\subsection{Tax treatment of transfer prices in Europa}

Most European countries apply OECD Guidelines in regulating transfer pricing issues. Also, many countries (primarily EU members) are turning toward the application of instruments and solutions offered by the EU Joint Transfer Pricing Forum (established in 2002), putting an emphasis on removing obstacles in domestic legislation for their implementation. However, for some countries, the main limiting factor is still the lack of capacity of tax authorities to tackle disputed tax issues in the field of transfer pricing. Below are the general rules for applying transfer pricing in individual European countries, classified by EU membership.

Table 3. Summary of transfer pricing tax treatment in selected European countries (EU Member States)

\begin{tabular}{|l|c|c|c|c|c|}
\hline Country & Malta & Hungary & Slovenia & Croatia & Spain \\
\hline $\begin{array}{l}\text { Corporate income } \\
\text { tax rate }\end{array}$ & $35 \%$ & $9 \%$ & $19 \%$ & $18 \%$ & $25 \%$ \\
\hline Regulation type & National regulations & OECD & OECD & $\begin{array}{c}\text { OECD (although } \\
\text { Croatia is not a } \\
\text { member }\end{array}$ & OECD \\
\hline $\begin{array}{l}\text { Transfer pricing } \\
\text { regulations }\end{array}$ & $\begin{array}{c}\text { No (but the arm's } \\
\text { length principle has } \\
\text { been incorporated } \\
\text { into other } \\
\text { regulations) }\end{array}$ & $\begin{array}{c}\text { Yes (OECD } \\
\text { Guidelines are } \\
\text { used) }\end{array}$ & $\begin{array}{c}\text { Yes (OECD } \\
\text { Guidelines are } \\
\text { used) }\end{array}$ & $\begin{array}{c}\text { Yes (OECD } \\
\text { Guidelines are } \\
\text { used) }\end{array}$ & $\begin{array}{c}\text { Yes (OECD } \\
\text { Guidelines are } \\
\text { used) }\end{array}$ \\
\hline $\begin{array}{l}\text { Transfer pricing } \\
\text { methods }\end{array}$ & $\begin{array}{c}\text { Yes (all methods } \\
\text { listed in the } \\
\text { OECD } \\
\text { Guidelines) }\end{array}$ & $\begin{array}{c}\text { Yes (all methods } \\
\text { listed in the } \\
\text { OECD } \\
\text { Guidelines) }\end{array}$ & $\begin{array}{c}\text { Yes (all methods } \\
\text { listed in the } \\
\text { OECD } \\
\text { Guidelines) }\end{array}$ & $\begin{array}{c}\text { Yes (all methods } \\
\text { listed in the } \\
\text { OECD }\end{array}$ \\
Guidelines)
\end{tabular}




\begin{tabular}{|c|c|c|c|c|c|}
\hline $\begin{array}{l}\text { request by tax } \\
\text { authorities }\end{array}$ & & & & & \\
\hline $\begin{array}{l}\text { Tax penalties for } \\
\text { underestimation of } \\
\text { tax base based on } \\
\text { the use of transfer } \\
\text { pricing }\end{array}$ & Not regulated & $\begin{array}{c}50 \% \\
\text { underestimated } \\
\text { tax liability }\end{array}$ & $\begin{array}{c}30-45 \% \text { of } \\
\text { underestimated } \\
\text { tax liability }\end{array}$ & $\begin{array}{c}\text { Up to } \approx 26.900,00 \\
€ \text { (converted } \\
\text { amount) }\end{array}$ & Not defined \\
\hline$A P A$ & No & Yes & Yes & Yes & Yes \\
\hline $\begin{array}{l}\text { Time limit for } \\
\text { concluding } A P A\end{array}$ & - & $\begin{array}{l}5 \text { years (with } \\
\text { possibility of } \\
\text { extension for } 3 \\
\text { more years) }\end{array}$ & Not defined & Not defined & Maximum 6 years \\
\hline$B E P S$ & $\begin{array}{l}\text { Not incorporated } \\
\text { into legal } \\
\text { regulations }\end{array}$ & $\begin{array}{c}\text { Partly } \\
\text { incorporated into } \\
\text { legal regulations }\end{array}$ & $\begin{array}{l}\text { Incorporated into } \\
\text { legal regulations }\end{array}$ & $\begin{array}{l}\text { Not incorporated } \\
\text { into legal } \\
\text { regulations }\end{array}$ & $\begin{array}{l}\text { Incorporated into } \\
\text { legal regulations }\end{array}$ \\
\hline $\begin{array}{l}\text { Databases for } \\
\text { comparing } \\
\text { controlled and } \\
\text { uncontrolled } \\
\text { transactions }\end{array}$ & Do not apply & Amadeus & $\begin{array}{c}\text { Amadeus, ORBIS, } \\
\text { ktMine }\end{array}$ & Amadeus, ORBIS & Amadeus \\
\hline
\end{tabular}

Source: Table created by the author, based on data EY (2017/18), PKF (2017/18), Deloitte (2018), KPMG (2018), OECD (2018), PwC (2018), Tax Foundation (2018)

The average corporate income tax rate in EU is $21.29 \%$ (according to KPMG). EU Member States rely mainly on OECD regulations (among the countries under consideration the exception is Malta, which has the highest corporate income tax rate in the EU, according to the Tax Foundation). There are no separate rules on transfer pricing in all EU countries. In most countries, it is legal defined which transfer pricing methods may be applied. Transfer pricing documentation is mandatory, although in some EU Member States no deadline for its submission (e.g. Malta) has been defined, nor have separate tax penalties for the transfer pricing area (e.g. Malta, Spain) been defined. Legislation allows the application of APA, but in certain countries (such as Slovenia and Croatia) the maximum limitation of their duration is not defined. The incorporation of the BEPS project into legal regulation is differently regulated in EU Member States, with most of them mainly relying on the use of the Amadeus database when comparing controlled and uncontrolled transactions.

Table 4. Summary of transfer pricing tax treatment in selected European countries (non-EU countries)

\begin{tabular}{|c|c|c|c|c|c|}
\hline Country & Albania & Russia & Serbia & Turkey & Montenegro \\
\hline $\begin{array}{l}\text { Corporate income } \\
\text { tax rate }\end{array}$ & $15 \%$ & $20 \%$ & $15 \%$ & $22 \%$ & $9 \%$ \\
\hline Regulation type & $\begin{array}{l}\text { OECD (although } \\
\text { Albania is not a } \\
\text { member) }\end{array}$ & $\begin{array}{l}\text { National } \\
\text { regulations (in } \\
\text { line with the } \\
\text { OECD, } \\
\text { although } \\
\text { Russia is not a } \\
\text { member) }\end{array}$ & $\begin{array}{l}\text { National regulations } \\
\text { (based on the } \\
\text { OECD, although } \\
\text { Serbia is not a } \\
\text { member) }\end{array}$ & National regulations & $\begin{array}{l}\text { National } \\
\text { regulations } \\
\text { (poorly supported } \\
\text { by the OECD } \\
\text { Guidelines). }\end{array}$ \\
\hline $\begin{array}{l}\text { Transfer pricing } \\
\text { regulations }\end{array}$ & $\begin{array}{c}\text { Yes (OECD } \\
\text { Guidelines are } \\
\text { used) }\end{array}$ & $\begin{array}{c}\text { Yes (OECD } \\
\text { Guidelines are } \\
\text { used) }\end{array}$ & $\begin{array}{c}\text { Yes (OECD } \\
\text { Guidelines are used) }\end{array}$ & Yes & Yes \\
\hline $\begin{array}{l}\text { Transfer pricing } \\
\text { methods }\end{array}$ & $\begin{array}{l}\text { Yes (all methods } \\
\text { listed in the } \\
\text { OECD } \\
\text { Guidelines) }\end{array}$ & $\begin{array}{c}\text { Yes (all } \\
\text { methods listed } \\
\text { in the OECD } \\
\text { Guidelines) }\end{array}$ & $\begin{array}{c}\text { Yes (all methods } \\
\text { listed in the OECD } \\
\text { Guidelines, with the } \\
\text { possibility of } \\
\text { applying any other } \\
\text { method if the }\end{array}$ & $\begin{array}{l}\text { Yes (all methods } \\
\text { listed in the OECD } \\
\text { Guidelines, while } \\
\text { preference is given } \\
\text { to traditional } \\
\text { transactional }\end{array}$ & $\begin{array}{l}\text { Traditional } \\
\text { transaction } \\
\text { methods } \\
\text { (preference is } \\
\text { given to } \\
\text { comparable } \\
\end{array}$ \\
\hline
\end{tabular}




\begin{tabular}{|c|c|c|c|c|c|}
\hline & & & $\begin{array}{l}\text { application of other } \\
\text { five methods is not } \\
\text { possible) }\end{array}$ & methods) & $\begin{array}{l}\text { uncontrolled price } \\
\text { method). }\end{array}$ \\
\hline $\begin{array}{l}\text { Transfer pricing } \\
\text { documentation }\end{array}$ & Yes & Yes & Yes & $\begin{array}{l}\text { Yes (the volume of } \\
\text { required } \\
\text { documentation is } \\
\text { conditioned by the } \\
\text { size of the business } \\
\text { entity) }\end{array}$ & Yes \\
\hline $\begin{array}{l}\text { Requirements to } \\
\text { prepare } \\
\text { documentation } \\
\text { annually }\end{array}$ & Not defined & $\begin{array}{l}\text { May } 20 \text { (for the } \\
\text { previous year) }\end{array}$ & $\begin{array}{l}\text { With the annual tax } \\
\text { return }\end{array}$ & $\begin{array}{l}\text { April } 25 \text { (for the } \\
\text { previous year) }\end{array}$ & $\begin{array}{l}\text { With the annual } \\
\text { tax return }\end{array}$ \\
\hline $\begin{array}{l}\text { Submission deadline } \\
\text { upon request by tax } \\
\text { authorities }\end{array}$ & 30 days & 30 days & 30-90 days & 15 days & Not defined \\
\hline $\begin{array}{l}\text { Tax penalties for } \\
\text { underestimation of } \\
\text { tax base based on the } \\
\text { use of transfer } \\
\text { pricing }\end{array}$ & $\begin{array}{l}70,00 € \text { (for each } \\
\text { month of delay) }\end{array}$ & $\begin{array}{l}40 \% \text { of the } \\
\text { determined tax } \\
\text { surcharge }\end{array}$ & $\begin{array}{l}30 \% \text { of the value of } \\
\text { the additional tax } \\
\text { liability (minimum } \\
\approx 1.700,00 €, \\
\text { converted amount) }\end{array}$ & Not defined & Not defined \\
\hline$A P A$ & Yes & Yes & No & Yes & No \\
\hline $\begin{array}{l}\text { Time limit for } \\
\text { concluding } A P A\end{array}$ & 5 years & $\begin{array}{l}3 \text { years (with } \\
\text { the possibility } \\
\text { of } 2 \text { years } \\
\text { extension) }\end{array}$ & - & 3 years & - \\
\hline BEPS & $\begin{array}{l}\text { Not incorporated } \\
\text { into legal } \\
\text { regulations }\end{array}$ & $\begin{array}{l}\text { Incorporated } \\
\text { into legal } \\
\text { regulations }\end{array}$ & $\begin{array}{l}\text { Not incorporated } \\
\text { into legal } \\
\text { regulations }\end{array}$ & $\begin{array}{l}\text { Not incorporated } \\
\text { into legal regulations }\end{array}$ & $\begin{array}{l}\text { Not incorporated } \\
\text { into legal } \\
\text { regulations }\end{array}$ \\
\hline $\begin{array}{l}\text { Databases for } \\
\text { comparing controlled } \\
\text { and uncontrolled } \\
\text { transactions }\end{array}$ & Do not apply & Do not apply & Do not apply & $\begin{array}{c}\text { Amadeus, Thomson } \\
\text { Reuters }\end{array}$ & Do not apply \\
\hline
\end{tabular}

Source: Table created by the author, based on data EY (2017/18), PKF (2017/18), Deloitte (2018), KPMG (2018), OECD (2018), PwC (2018), Tax Foundation (2018)

The average corporate income tax rate in Europe is 19.48\% (according to KPMG), which indicates that non-EU European countries generally have lower corporate income tax rates. Observed non-EU European countries regulate tax issues mainly based on OECD regulations or national ones that are differently aligned with the OECD. For the most part, all transfer pricing methods specified in the OECD Guidelines are legally permitted (among the countries under consideration the exception is Montenegro, where only traditional transactional methods are allowed), and in some countries (such as Serbia) other methods in accordance with the arm's length principle are also permitted. Transfer pricing documentation is mandatory, although penalties for their tax abuse are imposed in some countries, while in others countries these penalties are not legally defined. APAs are permitted in some countries. The BEPS project is generally not incorporated into the legal regulations of non-EU European countries (among the countries under consideration the exception is Russia). Also, in most countries, tax authorities do not use databases to compare controlled with uncontrolled transactions.

\subsection{Tax treatment of transfer prices in Asia}

The issue of transfer prices has been much popularized in the countries of Asia over the past few years. Although each jurisdiction has its own tax specifics, a trend to increase 


\section{standardization of the transfer pricing practical application and control within each} regime, and to a certain extent, across the region, is generally encouraged.

Table 5. Summary of transfer pricing tax treatment in selected Asian countries

\begin{tabular}{|c|c|c|c|c|c|}
\hline Country & India & Japan & Qatar & Korea & Hong Kong \\
\hline $\begin{array}{l}\text { Corporate } \\
\text { income tax rate }\end{array}$ & $35 \%$ & $30.86 \%$ & $10 \%$ & $25 \%$ & $16.5 \%$ \\
\hline Regulation type & $\begin{array}{l}\text { OECD (although } \\
\text { India is not a } \\
\text { member, but has } \\
\text { achieved intensive } \\
\text { cooperation with } \\
\text { the OECD) }\end{array}$ & $\begin{array}{l}\text { National regulations (in line } \\
\text { with the OECD) }\end{array}$ & $\begin{array}{l}\text { National } \\
\text { regulations (in line } \\
\text { with the OECD) }\end{array}$ & OECD & $\begin{array}{c}\text { National } \\
\text { regulations (in line } \\
\text { with the OECD, } \\
\text { although Hong } \\
\text { Kong is not a } \\
\text { member) }\end{array}$ \\
\hline $\begin{array}{l}\text { Transfer pricing } \\
\text { regulations }\end{array}$ & $\begin{array}{c}\text { Yes (OECD } \\
\text { Guidelines are } \\
\text { used) }\end{array}$ & $\begin{array}{l}\text { Yes (OECD Guidelines are } \\
\text { used, but in case of non- } \\
\text { compliance, priority is given } \\
\text { to national regulations) }\end{array}$ & Yes & Yes & $\begin{array}{c}\text { Yes (OECD } \\
\text { Guidelines are } \\
\text { used) }\end{array}$ \\
\hline $\begin{array}{l}\text { Transfer pricing } \\
\text { methods }\end{array}$ & $\begin{array}{l}\text { Yes (all methods } \\
\text { listed in the } \\
\text { OECD } \\
\text { Guidelines) }\end{array}$ & $\begin{array}{l}\text { Yes (all methods listed in the } \\
\text { OECD Guidelines) }\end{array}$ & $\begin{array}{l}\text { Yes (all methods } \\
\text { listed in the } \\
\text { OECD Guidelines, } \\
\text { while preference } \\
\text { is given to } \\
\text { comparable } \\
\text { uncontrolled price } \\
\text { method) }\end{array}$ & $\begin{array}{l}\text { Yes (all } \\
\text { methods } \\
\text { listed in the } \\
\text { OECD } \\
\text { Guidelines) }\end{array}$ & $\begin{array}{c}\text { Yes (all methods } \\
\text { listed in the OECD } \\
\text { Guidelines) }\end{array}$ \\
\hline $\begin{array}{l}\text { Transfer pricing } \\
\text { documentation }\end{array}$ & Yes & Yes & $\begin{array}{l}\text { No (the law does } \\
\text { not explicitly state } \\
\text { the obligation to } \\
\text { keep records, but } \\
\text { is expected to } \\
\text { exist in practice) }\end{array}$ & Yes & No \\
\hline $\begin{array}{l}\text { Requirements to } \\
\text { prepare } \\
\text { documentation } \\
\text { annually }\end{array}$ & $\begin{array}{l}\text { Up to the date of } \\
\text { submission of the } \\
\text { annual tax return }\end{array}$ & $\begin{array}{l}\text { At the request of the } \\
\text { competent authority }\end{array}$ & - & $\begin{array}{l}\text { Up to the } \\
\text { date of } \\
\text { submission } \\
\text { of the annual } \\
\text { tax return } \\
\end{array}$ & - \\
\hline $\begin{array}{l}\text { Tax penalties } \\
\text { for } \\
\text { underestimation } \\
\text { of tax base } \\
\text { based on the use } \\
\text { of transfer } \\
\text { pricing }\end{array}$ & $\begin{array}{l}100-300 \% \text { of the } \\
\text { determined tax } \\
\text { surcharge }\end{array}$ & Not defined & Not defined & $73.000,00 €$ & Not defined \\
\hline$A P A$ & Yes & Yes & No & Yes & Yes \\
\hline $\begin{array}{l}\text { Time limit for } \\
\text { concluding } A P A\end{array}$ & Maximum 5 years & $\begin{array}{c}\text { 3-5 years (retroactive } \\
\text { activation is only possible } \\
\text { with bilateral arrangements) }\end{array}$ & - & 5 years & $3-5$ years \\
\hline$B E P S$ & $\begin{array}{l}\text { Partly } \\
\text { incorporated into } \\
\text { legal regulations }\end{array}$ & $\begin{array}{l}\text { Partly incorporated into legal } \\
\text { regulations }\end{array}$ & $\begin{array}{l}\text { Not incorporated } \\
\text { into legal } \\
\text { regulations }\end{array}$ & $\begin{array}{l}\text { Partly } \\
\text { incorporated } \\
\text { into legal } \\
\text { regulations } \\
\end{array}$ & $\begin{array}{l}\text { Not incorporated } \\
\text { into legal } \\
\text { regulations }\end{array}$ \\
\hline $\begin{array}{l}\text { Databases for } \\
\text { comparing } \\
\text { controlled and } \\
\text { uncontrolled } \\
\text { transactions }\end{array}$ & $\begin{array}{c}\text { Prowess, } \\
\text { CapitalinePlus }\end{array}$ & Compustat, ORBIS & Do not apply & KIS-Line & Do not apply \\
\hline
\end{tabular}

Source: Table created by the author, based on data EY (2017/18), PKF (2017/18), Deloitte (2018), KPMG

(2018), OECD (2018), PwC (2018), Tax Foundation (2018) 
The average corporate income tax rate in Asia is $21.21 \%$ (according to KPMG). The regulation of tax issues in Asian countries is based on OECD regulations or national ones, which are aligned with the OECD (although some countries are not members). On this basis, regulations on transfer prices, as well as defined applicable transfer pricing methods have been formulated, while in certain countries (such as Qatar) priority is given to the application of a particular method, but in case of impossibility of its implementation, other methods are allowed which listed in the OECD Guidelines. Transfer pricing documentation is generally mandatory (among the countries under consideration the exceptions are Hong Kong and Qatar, although the Qatar tax authorities implicitly expect such documentation to exist), but in some countries penalties there are no penalties for violation or failure to comply with tax regulations on that basis (e.g. Japan). In most Asian countries, legal regulations allow the application of APAs (Qatar is the exception among the countries considered). In some Asian countries, the BEPS Action Plan is partly incorporated into legal regulations (certain actions apply, with defined conditions for their implementation). Competent tax authorities of some countries apply different databases for comparison of controlled and uncontrolled transactions, while in other countries their application is lacking.

\subsection{Tax treatment of transfer prices in Africa}

In terms of improving tax treatment of transfer pricing issues, an African countries rellie on the African Tax Administration Forum, which was established in 2008 and now consist of 36 member countries. In cooperation with the OECD, the work of the African Tax Administration Forum is focused on improving tax systems across Africa, that is, building strong, effective and efficient tax systems, in order to prevent the erosion of their tax bases.

Table 6. Summary of transfer pricing tax treatment in selected African countries

\begin{tabular}{|c|c|c|c|c|c|}
\hline Country & Egypt & Zambia & South Africa & Kenya & Uganda \\
\hline $\begin{array}{l}\text { Corporate income } \\
\text { tax rate }\end{array}$ & $22.5 \%$ & $35 \%$ & $28 \%$ & $\begin{array}{c}30 \% \text { (residents) } \\
37.5 \% \text { (nonresidents) }\end{array}$ & $30 \%$ \\
\hline Regulation type & $\begin{array}{l}\text { National } \\
\text { regulations (in } \\
\text { line with the } \\
\text { OECD, } \\
\text { although Egypt } \\
\text { is not a } \\
\text { member) }\end{array}$ & $\begin{array}{l}\text { National } \\
\text { regulations }\end{array}$ & $\begin{array}{c}\text { National } \\
\text { regulations (in } \\
\text { line with the } \\
\text { OECD, although } \\
\text { South Africa is } \\
\text { not a member, } \\
\text { but has achieved } \\
\text { intensive } \\
\text { cooperation with } \\
\text { the OECD) }\end{array}$ & National regulations & $\begin{array}{c}\text { National } \\
\text { regulations (in } \\
\text { line with the } \\
\text { OECD, although } \\
\text { Uganda is not a } \\
\text { member) }\end{array}$ \\
\hline $\begin{array}{l}\text { Transfer pricing } \\
\text { regulations }\end{array}$ & $\begin{array}{l}\text { Yes (OECD } \\
\text { Guidelines are } \\
\text { used) }\end{array}$ & $\begin{array}{c}\text { Yes (OECD } \\
\text { Guidelines are } \\
\text { used, although } \\
\text { Zambia is not a } \\
\text { member) }\end{array}$ & $\begin{array}{l}\text { Yes (OECD } \\
\text { Guidelines are } \\
\text { used) }\end{array}$ & Yes & $\begin{array}{c}\text { Yes (OECD } \\
\text { Guidelines are } \\
\text { used) }\end{array}$ \\
\hline $\begin{array}{l}\text { Transfer pricing } \\
\text { methods }\end{array}$ & $\begin{array}{l}\text { Yes (only some } \\
\text { of the methods } \\
\text { listed in the } \\
\text { OECD } \\
\text { Guidelines) }\end{array}$ & $\begin{array}{l}\text { Yes (all } \\
\text { methods listed } \\
\text { in the OECD } \\
\text { Guidelines) }\end{array}$ & $\begin{array}{l}\text { Yes (all methods } \\
\text { listed in the } \\
\text { OECD } \\
\text { Guidelines) }\end{array}$ & $\begin{array}{l}\text { Yes (all methods listed } \\
\text { in the OECD } \\
\text { Guidelines) }\end{array}$ & $\begin{array}{l}\text { Yes (all methods } \\
\text { listed in the } \\
\text { OECD } \\
\text { Guidelines) }\end{array}$ \\
\hline Transfer pricing & Yes & Yes & Yes (but only as & Yes & Yes \\
\hline
\end{tabular}




\begin{tabular}{|c|c|c|c|c|c|}
\hline documentation & & & $\begin{array}{l}\text { evidence of the } \\
\text { arm's length } \\
\text { principle } \\
\text { application for } \\
\text { controlled cross- } \\
\text { border } \\
\text { transactions) }\end{array}$ & & \\
\hline $\begin{array}{l}\text { Requirements to } \\
\text { prepare } \\
\text { documentation } \\
\text { annually }\end{array}$ & $\begin{array}{l}\text { With the annual } \\
\text { tax return }\end{array}$ & Not defined & Not defined & Not defined & Not defined \\
\hline $\begin{array}{l}\text { Submission deadline } \\
\text { upon request by tax } \\
\text { authorities }\end{array}$ & 45 days & 14 days & Immediately & Immediately & Not defined \\
\hline $\begin{array}{l}\text { Tax penalties for } \\
\text { underestimation of } \\
\text { tax base based on } \\
\text { the use of transfer } \\
\text { pricing }\end{array}$ & Not defined & $\begin{array}{c}\approx 8.900,00 € \\
\text { (converted } \\
\text { amount) }\end{array}$ & Not defined & Not defined & $\begin{array}{c}20 \% \text { од утврђене } \\
\text { доплате пореза }\end{array}$ \\
\hline$A P A$ & Yes & No & No & No & Yes \\
\hline $\begin{array}{l}\text { Time limit for } \\
\text { concluding } A P A\end{array}$ & Not defined & - & - & - & Not defined \\
\hline$B E P S$ & $\begin{array}{c}\text { Partly } \\
\text { incorporated } \\
\text { into legal } \\
\text { regulations }\end{array}$ & $\begin{array}{c}\text { Not } \\
\text { incorporated } \\
\text { into legal } \\
\text { regulations }\end{array}$ & $\begin{array}{c}\text { Partly } \\
\text { incorporated into } \\
\text { legal regulations }\end{array}$ & $\begin{array}{l}\text { Not incorporated into } \\
\text { legal regulations }\end{array}$ & $\begin{array}{l}\text { Not incorporated } \\
\text { into legal } \\
\text { regulations }\end{array}$ \\
\hline $\begin{array}{l}\text { Databases for } \\
\text { comparing } \\
\text { controlled and } \\
\text { uncontrolled } \\
\text { transactions }\end{array}$ & Do not apply & Do not apply & Do not apply & Do not apply & Do not apply \\
\hline
\end{tabular}

Source: Table created by the author, based on data EY (2017/18), PKF (2017/18), Deloitte (2018), KPMG (2018), OECD (2018), PwC (2018), Tax Foundation (2018)

The average corporate income tax rate in Africa is $28.26 \%$ (according to KPMG). In some African countries (such as Kenya), corporate tax rates are set differently for residents and nonresidents. Tax issues related to transfer pricing are governed by national regulations, but they are largely compliant with OECD regulations (among the countries under consideration the exceptions are Zambia and Kenya). Transfer pricing regulations and prescribed transfer pricing methods rely on the OECD Guidelines. Transfer pricing documentation is mandatory (although in some countries, such as South Africa, it is only required as evidence of the application of the arm's length principle for cross-border controlled transactions) but generally the legal deadline for submitting is not specified (Egypt is the exception among the countries considered), but in some countries it is expected to be provided upon request by tax authorities. Tax penalties based on non-compliance with transfer pricing regulations are not legally established in most countries. There is generally no regulation of APAs, but in countries where they exist, the time limit for their conclusion is not precisely defined. The BEPS project is only partially (with defined conditions for implementation) incorporated into legal regulations in certain countries, while databases for comparing controlled and uncontrolled transactions are not applied at all.

\subsection{Tax treatment of transfer prices in Oceania}

The (non)compliance of tax solutions for transfer pricing in Oceania for the selected countries is shown in the following table. 
Table 7. Summary of transfer pricing tax treatment in selected Oceania countries

\begin{tabular}{|c|c|c|c|c|}
\hline Country & Australia & New Zealand & Papa New Guinea & Fiji \\
\hline $\begin{array}{l}\text { Corporate income tax } \\
\text { rate }\end{array}$ & $30 \%$ & $28 \%$ & $\begin{array}{c}30 \% \text { (residents) } \\
48 \% \\
\text { (nonresidents) }\end{array}$ & $20 \%$ \\
\hline Regulation type & OECD & OECD & $\begin{array}{c}\text { National } \\
\text { regulations }\end{array}$ & National regulations \\
\hline $\begin{array}{l}\text { Transfer pricing } \\
\text { regulations }\end{array}$ & $\begin{array}{l}\text { Yes (OECD Guidelines } \\
\text { are used) }\end{array}$ & $\begin{array}{c}\text { Yes (OECD Guidelines are } \\
\text { used) }\end{array}$ & $\begin{array}{c}\text { Yes (OECD } \\
\text { Guidelines are } \\
\text { used, although } \\
\text { Papa New Guinea } \\
\text { is not a member) }\end{array}$ & $\begin{array}{c}\text { Yes (OECD } \\
\text { Guidelines are used, } \\
\text { although Fiji is not a } \\
\text { member) }\end{array}$ \\
\hline $\begin{array}{l}\text { Transfer pricing } \\
\text { methods }\end{array}$ & $\begin{array}{l}\text { Yes (all methods listed in } \\
\text { the OECD Guidelines) }\end{array}$ & $\begin{array}{l}\text { Yes (all methods listed in } \\
\text { the OECD Guidelines, while } \\
\text { preference is given to } \\
\text { traditional transactional } \\
\text { methods) }\end{array}$ & $\begin{array}{l}\text { Yes (all methods } \\
\text { listed in the OECD } \\
\text { Guidelines) }\end{array}$ & $\begin{array}{c}\text { Yes (all methods listed } \\
\text { in the OECD } \\
\text { Guidelines) }\end{array}$ \\
\hline $\begin{array}{l}\text { Transfer pricing } \\
\text { documentation }\end{array}$ & Yes & $\begin{array}{l}\text { Yes (but only as a statement } \\
\text { that the controlled } \\
\text { transactions are in } \\
\text { accordance with the arm's } \\
\text { length principle) }\end{array}$ & Yes & Yes \\
\hline $\begin{array}{l}\text { Requirements to } \\
\text { prepare } \\
\text { documentation } \\
\text { annually }\end{array}$ & $\begin{array}{l}\text { With the annual tax } \\
\text { return }\end{array}$ & Not defined & $\begin{array}{l}\text { Up to the date of } \\
\text { submission of the } \\
\text { annual tax return }\end{array}$ & $\begin{array}{l}\text { Up to the date of } \\
\text { submission of the } \\
\text { annual tax return }\end{array}$ \\
\hline $\begin{array}{l}\text { Submission deadline } \\
\text { upon request by tax } \\
\text { authorities }\end{array}$ & 21-28 days & 30 days & Not defined & Not defined \\
\hline $\begin{array}{l}\text { Tax penalties for } \\
\text { underestimation of } \\
\text { tax base based on the } \\
\text { use of transfer } \\
\text { pricing }\end{array}$ & $\begin{array}{l}50 \% \text { of the determined } \\
\text { tax surcharge }\end{array}$ & $\begin{array}{c}20-150 \% \text { of the determined } \\
\text { tax surcharge }\end{array}$ & $\begin{array}{l}\text { between } \approx 270,00 \\
€ \text { and } \approx 13.140,00 € \\
\text { (converted } \\
\text { amounts) }\end{array}$ & $\begin{array}{l}20-75 \% \text { of the } \\
\text { determined tax } \\
\text { surcharge }\end{array}$ \\
\hline$A P A$ & Yes & Yes & Yes & No \\
\hline $\begin{array}{l}\text { Time limit for } \\
\text { concluding } A P A\end{array}$ & 3-5 years & $\begin{array}{c}\text { Not defined (in practice, } 5 \\
\text { years) }\end{array}$ & Not defined & - \\
\hline$B E P S$ & $\begin{array}{l}\text { Incorporated into legal } \\
\text { regulations }\end{array}$ & $\begin{array}{l}\text { Incorporated into legal } \\
\text { regulations }\end{array}$ & $\begin{array}{l}\text { Not incorporated } \\
\text { into legal } \\
\text { regulations }\end{array}$ & $\begin{array}{l}\text { Not incorporated into } \\
\text { legal regulations }\end{array}$ \\
\hline $\begin{array}{l}\text { Databases for } \\
\text { comparing controlled } \\
\text { and uncontrolled } \\
\text { transactions }\end{array}$ & Do not apply & Do not apply & Do not apply & Do not apply \\
\hline
\end{tabular}

Source: Table created by the author, based on data EY (2017/18), PKF (2017/18), Deloitte (2018), KPMG (2018), OECD (2018), PwC (2018), Tax Foundation (2018)

The average corporate income tax rate in Oceania is $28.43 \%$ (according to KPMG). In some Oceania countries (e.g. Papua New Guinea), different rates for the taxation of corporate income are prescribed depending on residency status. In Oceania countries that have OECD membership status, regulation of tax matters is enforced by OECD regulations, while in countries that do not have this status, tax issues are governed by national regulations. The transfer pricing regulations are in line with the OECD Guidelines and all the methods outlined in the Guidelines have been legally confirmed, while in tax legislation of some countries (e.g. New Zealand) traditional transactional methods are preferred. Transfer pricing documentation is mandatory, but the submitting deadlines are different (in some countries, such as New Zealand, it is not defined at all). The tax penalties for derogation from the established transfer tax 
regulations differ significantly from country to country. The application of APA is permitted in most countries (among the countries under consideration the exception is Fiji), but in some of them (such as New Zealand and Papua New Guinea), their time limit is not specified. The BEPS project is incorporated into legal regulations of some countries (e.g. Australia, New Zealand), while databases for comparison of controlled with uncontrolled transactions are not applied.

\section{Conclusion}

Certain international and regional organizations have endeavored, by adopting appropriate guidelines, manuals, action plans, codes and other publications, and by launching various tax support programs, to provide appropriate technical assistance, advice and financial assistance, in order to reduce the freedom in defining transfer pricing and ensure objectivity and fairness in taxation at the global level. But significant differences in tax regulation remain an appropriate area for achieving the specific goals of group members, as well as the economic group itself, in applying transfer pricing.

To a certain extent, most countries (worldwide) have accepted and implemented internationally adopted solutions and guidelines in the field of transfer pricing. However, differences in domain and degree of implementation are present not only between individual continents and the region, but also within them, and even within the framework of international economic integrations (such as the European Union). Also, on the other hand, certain countries (worldwide), despite the aforementioned support, due to ignorance of the competent authorities or as a consequence of prioritising other segments of tax interests, did not provide even elementary legal regulations in order to regulate the issue of transfer pricing.

The inconsistencies shown, the incompleteness of national regulations, and the absence of legislation in certain segments of the tax formulation of their application in individual countries (even with the exception of 'tax havens'), with differences to the average corporate income tax rates between continents, but also within the continents themselves, intensify the misuse of transfer pricing. In other words, the variations noted, regardless of the global approach to solving the problem, remain an active focus of arbitrary transactions between related legal entities and, consequently, the achievement of certain tax savings on that basis.

For that reason, it is necessary to primarily raise awareness of legislative and executive institutions of the countries that have not paid adequate tax attention to this issue, of the importance and necessity of strengthening tax legislation related to this field, with the aim of building a comprehensive and complete legal framework based on internationally adopted solutions and guidelines. It is also necessary to improve and upgrade the expertise and relevant skills of local tax inspectors and create appropriate domicile electronic databases and provide access to existing (international) ones to facilitate and timely identify transfer pricing cases with the highest tax risk. In doing so, it is necessary to rely on the various support programs of international institutions 
and organizations, as well as on the experiences of other countries, through the establishment of appropriate tax treaties. Building adequate tax systems based on international guidelines and mutual cooperation between different countries would increase the compliance of existing regulations and narrow the scope for potential misuse of transfer prices globally.

\section{References}

Becker, J., Davies, R.B. \& Jakobs, G. (2017). The Economics of Advance Pricing Agreements. Journal of Economic Behavior \& Organization, 134(C), 255-268.

Buettner, T., Overesch, M. \& Wamser, G. (2018). Anti profit-shifting rules and foreign direct investment. International Tax and Public Finance, 25(3), 553-580.

Deloitte. (2018). The link Between Transfer Pricing and Customs Valuation (Country Guide). Retrived March 12, 2019, from

https://www2.deloitte.com/us/en/pages/tax/articles/transfer-pricing-customs-valuationcountry-guide.html

Europian Union. (2006). Code of Conduct on transfer pricing documentation for associated enterprises in the European Union. Official Journal of the European Union C 176/1. Retrived February 18, 2019, from https://eur-lex.europa.eu/legalcontent/EN/TXT/PDF/?uri=CELEX:42006X0728(01)\&from=EN

EY. (2017/18). Worldwide Transfer Pricing Reference Guide. Retrived March 6, 2019, from https://www.ey.com/Publication/vwLUAssets/ey-2017-2018-tp-referenceguide/\$FILE/ey-2017-2018-tp-reference-guide.pdf

Jansky, P. \& Prats, A. (2015). International Profit-Shifting out of Developing Countries and the Role of Tax Havens. Development Policy Review, 33(3), 271-292.

King, E. (2009). Transfer Pricing and Corporate Taxation: Problems, Practical Implications and Proposed Solutions. New York: Springer Science+Business Media, LLC.

KPMG. Corporate tax rates table. Retrived March 20, 2019, from https://home.kpmg/xx/en/home/services/tax/tax-tools-and-resources/tax-ratesonline/corporate-tax-rates-table.html

Negovanović, M., Čubrić, F. \& Lazović, G. (2015). Priručnik za transferne cene, Beograd: Privredni savetnik.

OECD. (2017). OECD Transfer Pricing Guidelines for Multinational Enterprises and Tax Administrations. Paris: OECD Publishing.

OECD. (2013). Action Plan on Base Erosion and Profit Shifting. Paris: OECD Publishing. 
OECD Tax Database. Table II.1 - Corporate income tax rates: basic/non-targeted. Retrived March 20, 2019, from

https://stats.oecd.org/index.aspx?DataSetCode=TABLE_II1

PKF International. (2017/18). PKF Worldwide Transfer Pricing Guide. Retrived March 12, 2019, from https://www.pkf.com/publications/tax-guides/pkf-worldwidetransfer-pricing-guide-2017-18/

PwC.Worldwide Tax Summaries - Corporate income tax rates. Retrived March 20, 2019, from http://taxsummaries.pwc.com/ID/Corporate-income-tax-(CIT)-rates

Sikka, P. \& Willmott, H., (April 2010), The dark side of transfer pricing: Its role in tax avoidance and wealth retentiveness, Critical Perspectives on Accounting, 21(4), 342356 ;

Tax Foundation.Corporate Income Tax Rates around the World, 2018. Retrived March 20, 2019, from https://files.taxfoundation.org/20181127165741/Corporate-Tax-RatesAround-the-World-2018.pdf

United Nation.(2017). Practical Manual on Transfer Pricingfor Developing Countries. New York: Department of Economic \& Social Affairs.

\section{Summary}

For decades, as an immanent tax factor, transfer pricing has preoccupied the interest of the academic, legislative and executive milieu of the developed countries, as well as prominent international organizations, which emphasizes the difficulty and complexity of managing and controlling this issues at local and international levels. Taking into account the harmonization of the national tax regulations of the selected countries with internationally adopted solutions and guidelines in the field of transfer pricing, it has been established in the paper that most countries (worldwide) have accepted and implemented that solutions and guidelines, but with certain variations in the domain and degree of implementation. Also, a number of countries have not properly regulated the issue of transfer prices, so the existing oscillations and inequalities, generally observed, continue to be an active area for relatively arbitrary performance of controlled transactions. 